\title{
Social Justice in Islam
}

\author{
Deina Abdelkader \\ Herndon, VA: International Institute of Islamic Thought, \\ 2000. 216 pages.
}

The dynamics of Islamic revival/activism have been the subject of renewed interest in the aftermath of the $9 / 11$ tragedy. Most of this interest has been confined to media sound bites that present little or no appreciation for the linkages between cause and effect, despite appeals by some conscientious commentators for balanced analysis. Deina Abdelkader's Social Justice in Islam, therefore, is a fresh contribution to studies on Islamic revivalism in its contemporary context. Even though the study covers the period from 1988 to 1993, its examination of revivalist (or, as Abdelkader prefers, activist) sentiment and activities in Egypt, Algeria, and Turkey through the dual lens of maqasid al-Shari 'ah (aims of Shari'ah) and the legal doctrine of maslahah (public good) is timely, for it connects popular sentiment to expression. The legal convention of maslahah and the paradigm of the maqasid serve as baselines from which the author seeks to create a method to understand the revivalists' thoughts and actions, as well as the feedback mechanisms created by them to understand how they must function in future contexts.

Abdelkader uses statistical analyses to examine the data in order to study the relationship between the maqasid and the levels of activism measured in each country. This lends her work credibility beyond the use of anecdotes, which is needed in contemporary social science research. The work is comprised of seven chapters followed by appendices that present the data collected for Egypt, Algeria, and Turkey. The chapters focus on theories of Islamic activism, the relationship between activism and public expectations, and the research methodology used. A glossary of Arabic terms is included, as well as an extensive bibliography. A preface is provided by Taha Jabir al-Alwani.

Abdelkader's first task is to review theories of Islamic activism/revival in order to provide the reader with an understanding of its real causes. She reviews three approaches used in the study of Islamic activism/revival: the modernization/economic development approach, which focuses on the dynamics of modernization; the popular discontent approach, which examines the sources and degree of mobilization of Islamic activism/revival; and the cultural studies approach, which emphasizes the customs and traditions 
of Islamic activism/revival. Her own approach stresses the cultural and historical background of Islamic activism/revival, and focuses on the expectations of Muslim societies in relation to local political systems and their programs. She prefers to use the popular discontent model, for she believes that it allows her to account for popular mobilization in relation to a state's failure to perform. Indeed, she tells us that her basic hypothesis is that the extent of Islamic activism is a function of the extent to which a state falls short of the principles of Islamic social justice, as understood through the maqasid.

The author examines popular mass mobilization through the maqasid. She writes that activists in each country examined speak of their grievances in relation to the maqasid, and that the activists' discourse seeks to promote the maslahah in achieving ends that uphold the public's welfare. She cites Rashid al-Ghanushi, Hasan al-Turabi, and Yusuf al-Qaradawi, among others, to support this position. Abdelkader also provides a good background on the development of maslahah and maqasid in the four Sunni legal schools of thought in order to trace their present-day usage. These concepts are seen as integral to Islamic cultures and to their quest for justice.

The methodology used takes into account the place of various factors in a society's conformity, or not, with principles from the maqasid. Abdelkader defines the independent variables through the various aspects of the maqasid. Consequently, the preservation, or lack thereof, of religion, the mind, the self, posterity, and wealth is seen as the motivating factor for activism (the dependant variable) in all of its aspects. In doing so, the study examines the place of religious education, torture, imprisonment, police brutality, and the level of state censorship as the constitutive elements of rises in activism, both violent and otherwise. Activism is measured by looking at the types and occurrences of demonstrations, attempted attacks or threats, and election dynamics. All data was collected through the use of Foreign Broadcast Information Service daily reports from October 1988 to September 1993.

When considering each of the three countries, a short history of its internal activist phenomenon is given for the 1980s and 1990s. This helps the reader understand the contexts of the research and the study's findings, which help link each country's societal conditions to the dynamics of Islamic activism/revival. Specifically, the study also seeks to create linkages between the type of activism adopted (e.g., violent vs. non-violent) and the specific element of the maqasid breached or violated (e.g., preservation of mind or religion). The findings help to open up interesting areas 
of further research that scholars may investigate, especially in light of current international tensions and the post-9/11 environment.

This is a unique and well-timed study. The book is well organized and clearly written, which reflects the author's clarity of purpose. It is a work that would be of interest to students and scholars of Islamic revival, legal thought, and international affairs. Its main contribution is in the connections it creates between popular discontent and activism through the system of the maqasid and the promotion of the public good. Furthermore, it gives the reader an indication of the mechanisms that societies use to voice their displeasure with the government's failure to promote the public's general welfare in line with Islamic values.

Saijjad Idris

Master of International Affairs

School of International and Public Affairs

Columbia University, New York 